\title{
Frequency of Cholelithiasis and Biliary Pathology in the Easter Island Rapanui and Non-Rapanui Populations
}

\author{
Eduardo Bravo*, Jorge Contardo, Jerson Cea
}

\begin{abstract}
Background: Chile is one of the countries with the highest prevalence of cholelithiasis worldwide, considering the Mapuche ethnicity as a risk factor for developing this pathology. Moreover, cholelithiasis is the main risk factor for developing gallbladder cancer, being the fifth cause of cancer death in Chile. The purpose of this study was to compare the frequency of cholelithiasis and biliary pathology among the population belonging to Rapanui ethnicity and non-Rapanui population living on Easter Island. Materials and Methods: In this retrospective case-control study, a total of 609 abdominal ultrasonographs performed consecutively in Hanga Roa Hospital during the period August 2012 to January 2015 were analyzed. Multiple logistic regression was used to obtain odds ratio (OR) and $95 \%$ confidence intervals (95\% CI) of cholelithiasis and biliary pathology, adjusting for age, gender and referral diagnostic hypothesis. Results: In the Rapanui population the frequency for cholelithiasis and biliary pathology was $6.4 \%$ and $13 \%$, meanwhile for the non-Rapanui population it was $13 \%$ and $22 \%$ respectively. Compared to the non-Rapanui Chilean population, the Rapanui ethnicity presented an OR of 0.53 (95\% CI: 0.29-0.95) for cholelithiasis and OR of 0.52 (95\% CI: 0.33-0.82) for biliary pathology. Conclusions: We found statistically significant ethnic differences in the frequency of cholelithiasis and biliary disease among the population of Rapanui and non-Rapanui ethnicity, so that this could be a protective factor for the development of biliary pathology, given the Chilean population context. Other studies including community population to determine the real prevalence of cholelithiasis and analyze the protective role of Rapanui ethnicity on this disease are necessary.
\end{abstract}

Keywords: Polynesia - cholelithiasis - biliary pathology - ethnic groups - Easter island

Asian Pac J Cancer Prev, 17 (3), 1485-1488

\section{Introduction}

Easter Island is a small territory, which marks the eastern Polynesian triangle vertex, one of the most isolated places in the world and that is under Chilean sovereignty since 1888. It is for centuries the home of the Rapanui culture, unique in the world and of origin Polynesian, which has experienced a progressive fusion of the local ethnic groups with Chileans and Europeans mainly (Englert, 2009; Stambuk, 2010), resulting in the 6370 people who currently living on Easter Island (INE, 2015).

Chile is one of the countries with the highest prevalence of cholelithiasis worldwide, being estimated that al least $26.7 \%$ of the adult Chilean population has or had cholelithiasis (Latorre et al., 2015). Particularly for the habitants of Easter Island, it has been reported a prevalence of $21 \%$ of cholelithiasis in Rapanui population (Miquel et al., 1998). There is a lithogenic gradient between ethnic groups, being the Mapuche population the most affected, among other risk factors described (Latorre et al., 2015). This information is relevant considering that about $95 \%$ of Chilean population has some degree of genetic mixing with the Mapuche ethnicity (Arcos-Burgos and Herrera, 2004). Moreover, cholelithiasis is the main risk factor for developing gallbladder cancer, being the fifth cause of cancer death in Chile, while this cause is uncommon in Rapanui population (Rius et al., 2013).

The ultrasound remains today the method of choice for the initial study of cholelithiasis and biliary disease, with sensitivity and specificity greater than $95 \%$ (McIntosh and Penney, 1980; Shea et al., 1994; Bortoff et al., 2000). It has the advantages of being a noninvasive test that does not use ionizing radiation, with easy access and low cost.

The purpose of this study is to compare the frequency of cholelithiasis and biliary disease among population belonging to Rapanui ethnicity and non-Rapanui residents living on Easter Island.

\section{Materials and Methods}

A retrospective case-control study was performed. A total of 653 abdominal ultrasonographies performed consecutively in Hanga Roa Hospital during the period August 2012 to January 2015, excluding 44 patients under 
Table 1. Characteristics of the Analyzed Population

\begin{tabular}{|c|c|c|c|c|}
\hline & $\begin{array}{l}\text { Rapanui } \\
(n=283)\end{array}$ & $\begin{array}{c}\text { Non- } \\
\text { Rapanui } \\
(n=326)\end{array}$ & $\begin{array}{c}\text { Total } \\
(\mathrm{n}=609)\end{array}$ & $\mathrm{P}$ value \\
\hline Gender & & & & $0.07 \mathrm{NS} *$ \\
\hline Male & $\begin{array}{c}89 \\
(41.6 \%)\end{array}$ & $\begin{array}{c}125 \\
(58.4 \%)\end{array}$ & 214 & \\
\hline Female & $\begin{array}{c}194 \\
(49.1 \%)\end{array}$ & $\begin{array}{c}201 \\
(50.9 \%)\end{array}$ & 395 & \\
\hline $\begin{array}{l}\text { Age } \\
\text { (years) }\end{array}$ & $\begin{array}{l}43.4 \pm \\
0.9 \mathrm{SD}\end{array}$ & $\begin{array}{c}45 \pm 0.7 \\
\mathrm{SD}\end{array}$ & & $0.13 \mathrm{NS}^{* *}$ \\
\hline \multicolumn{3}{|c|}{ Diagnostic Hypothesis } & & $0.85 \mathrm{NS}^{*}$ \\
\hline $\begin{array}{l}\text { Biliary } \\
\text { origin }\end{array}$ & $\begin{array}{c}53 \\
(45.7 \%)\end{array}$ & $\begin{array}{c}63 \\
(54.3 \%)\end{array}$ & 116 & \\
\hline Other & $\begin{array}{c}230 \\
(46.7 \%)\end{array}$ & $\begin{array}{c}263 \\
(53.3 \%)\end{array}$ & 493 & \\
\hline
\end{tabular}

*Chi-squared test; **Mann-Whitney U Test; NS: no significative difference; SD: standard deviation

Table 2. Frequency of Biliary Pathology by Ethnicity

\begin{tabular}{lccc}
\hline & $\begin{array}{c}\text { Rapanui } \\
(\mathrm{n}=283)\end{array}$ & $\begin{array}{c}\text { Non-Rapanui } \\
(\mathrm{n}=326)\end{array}$ & $\begin{array}{c}\text { Total } \\
(\mathrm{n}=609)\end{array}$ \\
\hline $\begin{array}{l}\text { Cholelithiasis } \\
\text { Present }\end{array}$ & $18(6.4 \%)$ & $37(11.3 \%)$ & 55 \\
Absent & $265(93.6 \%)$ & $289(88.7 \%)$ & 554 \\
Biliary Pathology* & & \\
Present & $37(13 \%)$ & $72(22 \%)$ & 109 \\
Absent & $246(87 \%)$ & $254(78 \%)$ & 500 \\
\hline
\end{tabular}

*Biliary pathology: cholelithiasis or cholecystectomy history
15 years of age, were analyzed. The variables considered were age (years), gender (female o male), the ethnicity (Rapanui o non-Rapanui), the diagnostic hypothesis of the treating physician, history of previous cholecystectomy or cholelithiasis, and echographic diagnosis of cholelithiasis consigned in the medical report. A single operator, general practitioner trained in abdominal ultrasound, performed the ultrasonographies. The diagnosis of cholelithiasis was corroborated by the report of the surgical biopsy after cholecystectomy.

In this study, was considered belonging to Rapanui ethnic group to the patients who carry at least one last name of Rapanui origin. The antecedent of cholecystectomy was provided by the patient and was checked with ultrasound examination. The diagnostic hypothesis was obtained from the medical request, grouped according suspected biliary pathology or not. The condition of biliary disease was considered in all the patients who had a history of previous cholecystectomy or that would be diagnosed with cholelithiasis after abdominal ultrasonography.

For the statistical analysis, the program Stata 9.0 was used. The quantitative variables were compared with Chisquare test, while for the age Mann-Whitney U test was utilized because the normal distribution of this parameter was rejected by Shapiro-Wilk test. For the analysis of the effect of the ethnicity on the frequency of cholelithiasis and biliary pathology, and adjust the size of the effect by gender, age and diagnostic hypothesis, we used an multiple logistic regression and were generated Odds Ratio (OR) and Confidence Intervals at $95 \%(95 \% \mathrm{CI})$, being set significance level at $\mathrm{p}<0.05$ bilateral.

Table 3. OR of Cholelithiasis for Rapanui Ethnicity Relative to non-Rapanui Population, Adjusted by Gender, Diagnostic Hypothesis and Age

\begin{tabular}{|c|c|c|c|c|c|c|}
\hline & OR & $\begin{array}{l}\text { Model } 1 \\
95 \% \text { CI }\end{array}$ & $\mathrm{P}$ value & OR & $\begin{array}{c}\text { Model } 2 \\
95 \% \text { CI }\end{array}$ & $P$ value \\
\hline Ethnicity & 0.55 & $0.30-0.98$ & 0.045 & 0.53 & $0.29-0.95$ & 0.035 \\
\hline Gender & & & & 1.61 & $0.85-3.09$ & 0.145 \\
\hline Diagnostic Hypothesis & & & & 0.97 & $0.47-2.01$ & 0.947 \\
\hline \multicolumn{7}{|l|}{ Age (years) } \\
\hline $15-31 *$ & & & & 1 & & \\
\hline $32-39$ & & & & 1.12 & $0.47-2.67$ & 0.796 \\
\hline $40-48$ & & & & 1.34 & $0.58-3.07$ & 0.486 \\
\hline $49-58$ & & & & 0.92 & $0.37-2.27$ & 0.851 \\
\hline$\geq 59$ & & & & 0.65 & $0.23-1.84$ & 0.415 \\
\hline
\end{tabular}

*Age range used for comparison.

Table 4. OR of Biliary Pathology for Rapanui Ethnicity Relative to non-Rapanui Population, Adjusted by Gender, Diagnostic Hypothesis and Age

\begin{tabular}{|c|c|c|c|c|c|c|}
\hline & \multicolumn{3}{|c|}{ Model 1} & \multicolumn{3}{|c|}{ Model 2} \\
\hline & OR & $95 \% \mathrm{CI}$ & $\mathrm{P}$ value & OR & $95 \% \mathrm{CI}$ & $\mathrm{P}$ value \\
\hline Ethnicity & 0.54 & $0.35-0.83$ & 0.003 & 0.52 & $0.33-0.82$ & 0.005 \\
\hline Gender & & & & 2.39 & $1.45-3.93$ & 0.001 \\
\hline Diagnostic Hypothesis & & & & 1.04 & $0.60-1.80$ & 0.871 \\
\hline \multicolumn{7}{|l|}{ Age (years) } \\
\hline $15-31 *$ & & & & 1 & & \\
\hline $32-39$ & & & & 1.47 & $0.64-3.38$ & 0.359 \\
\hline $40-48$ & & & & 3.14 & $1.47-6.67$ & 0.003 \\
\hline $49-58$ & & & & 2.89 & $1.33-6.27$ & 0.007 \\
\hline$\geq 59$ & & & & 4.40 & $2.02-9.53$ & 0.000 \\
\hline
\end{tabular}

*Age range used for comparison 


\section{Results}

A total of 609 patients were analyzed, of which $46.5 \%$ belong to the Rapanui ethnicity. No statistically significant differences between Rapanui and non-Rapanui populations about gender, age and diagnostic hypothesis were found (Table 1). In the Rapanui population, the frequency of cholelithiasis and biliary pathology was approximately half of that found in the non-Rapanui population (Table 2).

When comparing both populations, adjusting for potentially confounding variables, it was found that the Rapanui ethnicity presented an OR of 0.53 (95\% CI: 0.29 $-0.95, \mathrm{p}<0.035)$ for cholelithiasis (Table 3 ) and OR of 0.52 (95\% CI: $0.33-0.82, \mathrm{p}<0.005$ ) for biliary pathology (Table 4), compared to non-Rapanui population.

\section{Discussion}

We found statistically significant ethnic differences in the frequency of cholelithiasis and biliary disease among the population and the Rapanui ethnicity and nonRapanui, so that ethnicity could be a protective factor for the development of biliary pathology, given the Chilean population context. The importance of this point lies in the increased risk of gallbladder cancer in patients with cholelithiasis, so preventing their development and early diagnosis depend on detection of this major risk factor.

Of the 6370 habitants of Easter Island, 4805 are older than 15 years (INE, 2015), so eventually we analyzed to $12.7 \%$ of the eligible population, a number that we consider a representative percentage of the total population on this location. Considering that usually the most sick or symptomatic people come to the hospital, the frequency of biliary pathology in the Rapanui ethnic group population reached $13 \%$ in the sample analyzed in our study, lower than $21 \%$ prevalence of only cholelithiasis as previously reported (Miquel et al., 1998).

It is necessary to note that the island has the Hanga Roa Hospital as the only health center for the all the habitants, being the place where the ultrasonographic studies are performed. Only a small proportion of the people of Easter Island have the resources to travel to Continental Chile or French Polynesia for this type of test.

In this study is possible to identify several limitations to mention. Since this is a retrospective study was not possible to control other factors that might contribute to the analysis of the data obtained, for example, nutritional status of patients. There is a selection bias to include only patients who were referred by their physicians to perform abdominal ultrasonography, so the real community prevalence of cholelithiasis and biliary pathology is unknown. Another bias to mention is to assume that in all patients with prior cholecystectomy the indication was due to cholelithiasis, considering other conditions that justify this type of surgery. However, the most frequently histopathologic findings after cholecystectomy in Chile are due to cholelithiasis. (Seguel et al., 2007).

Performing abdominal ultrasonography by nonradiologist specialist, who has received appropiate training in this technique, has been shown to have proper diagnosis performance in the outpatient and emergency setting, as has been suggested in several national and international experiences in urban centers and rural locations (Steinmetz and Berger, 1999; Catan et al., 2002; Wordsworth and Scott, 2002; Speets et al., 2006; Esquerra et al., 2011; Sippel et al., 2011; Del Carpio et al., 2012).

Previously Drapkin (1935) studied the genetic composition of the "Rapanui pure blood" and he estimated that most of them had Caucasian blood type. In our study, the great majority of Rapanui participants in the sample had only one name belonging to the ethnic group, and it was estimated that about $50 \%$ of the population currently residing in Easter Island does not belong to the ethnic group. This tendency could determine a progressive increase in the prevalence of cholelithiasis in the population, research topic for the future.

To consider the Rapanui ethnicity as a protective factor for cholelithiasis and biliary pathology in relation to the Chilean population, is necessary a prospective study incorporating community population both symptomatic and asymptomatic, in order to determine the actual prevalence of this disease and to make comparisons with more representative samples.

\section{References}

Arcos-Burgos M,Herrera P (2004). Análisis de mezcla genética. In 'Poblaciones chilenas: cuatro décadas de investigaciones antropologicas'. Eds Rothhammer F and Llop E. Editorial Universitaria, Santiago, 241-67.

Bortoff G, Chen M, Ott D, et al (2000). Gallbladder stones: imaging and intervention. Radio Graphics, 20, 751-66.

Catan F, Altamirano C, Salas del CC, et al (2002). Ecografía realizada por cirujanos en el manejo de pacientes con trauma. Rev Med Chile, 130, 892-6.

Del Carpio M, Mercapide C, Salvitti J, et al (2012). Early diagnosis, treatment and follow-up of cystic echinococcosis in remote rural areas in Patagonia: impact of ultrasound training of non-specialists. PLOS Negl Trop Dis, 6, 1444.

Drapkin I (1935). Contribucion al estudio antropologico y demográfico de los Pascuenses. I de la Société des Américanistes, 27, 265-302.

Englert S (2009). Aspecto físico de la raza. In 'La tierra de Hotu Matua'. Ed Englert S. Rapa Nui Press, Easter Island, 203-25.

Esquerra M, Roura P, Masat T, et al (2012). Ecografía abdominal: una herramienta diagnostica al alcance de los médicos de familia. Aten Primaria, 44, 576-85.

Instituto Nacional de Estadísticas, INE (Chile) (2015). Actualizacion de poblacion 2002 - 2012 y proyecciones 2013 - 2020 [Online].

http://www.ine.cl/canales/chile_estadistico/familias/ demograficas_vitales.php.

Latorre G, Ivanovic-Zuvic D, Corsi O, et al (2015). Cobertura de la estrategia preventiva de cáncer de vesicula biliar en Chile: resultados de la Encuesta Nacional de Salud 2009 - 2010. Rev Med Chile, 143, 158-67.

McIntosh D, and Penney H (1980). Gray-scale ultrasonography as a screening procedure in the detection of gallbladder disease. Radiol, 136, 725-7.

Miquel J, Covarrubias C, Villarroel L, et al (1998). Genetic epidemiology of cholesterol cholelithiasis among Chilean Hispanics, Amerindians and Maoris. Gastroenterol, 115, 937-46.

Rius E, Yaikin P, Contreras G (2013). Cancer prevalence in 
Eduardo Bravo et al

Easter Island population - 2006-2010. Asian Pac J Cancer Prev, 14, 3101-3.

Seguel G, Fres E, Frez M, et al (2007). Naturaleza de los polipos de la vesícula biliar sometidos a colecistectomia. Rev Chil Cir, 59, 208-11.

Shea J, Berlin J, Escarce J, et al (1994). Revised estimates of diagnostic test sensitivity and specificity in suspected biliary tract disease. Arch Intern Med, 154, 2573-81.

Sippel S, Muruganandan K, Levine A, Shah S (2011). Review article: Use of ultrasound in the developing world. Int $J$ Emerg Med, 4, 72.

Speets A, Hoes A, van der Graaf Y, et al (2006). Upper abdominal ultrasound in general practice: indications, diagnostic yield and consequences for patient management. Fam Pract, 23, 507-11.

Stambuk P (2010). Los mestizos. in 'rongo, la historia oculta de isla de pascua'. ed stambuk p. editorial pehuen, Santiago, 65-85.

Steinmetz JP, and Berger JP (1999). Ultrasonography as an aid to diagnosis and treatment in a rural African hospital: a prospective study of 1,119 cases. Am J Trop Med Hyg, 60, 119-23.

Wordsworth S, and Scott A (2002). Ultrasound scanning by general practitioners: is it worthwhile? J Public Health Med, 24, 88-94. 